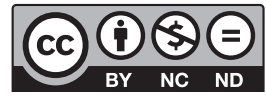

Estudos Teológicos foi licenciado com uma Licença Creative Commons Atribuição - NãoComercial - SemDerivados 3.0 Não Adaptada

http://dx.doi.org/10.22351/et.v60i2.4047

\title{
ESPERANÇA EM TEMPO DE PANDEMIA: APONTAMENTOS DA ESCATOLOGIA CONTEMPORÂNEA nO CONTEXTO dA Covid-19 1
}

\author{
Hope in times of pandemic: \\ reflections on contemporary eschatology in the context of Covid-19
}

Carlos Alberto Motta Cunha ${ }^{2}$

Resumo: A pandemia da Covid-19 escancara todas as desigualdades e as fissuras sociais. Ela revela ainda mais a crise existencial na qual o sujeito pós-moderno está inserido. A crise é global, afetando todos os âmbitos da vida: do sanitário ao econômico. A onda pandêmica deixa um rastro de morte e sofrimento. Nesse contexto, em isolamento social, emerge o tempo de perguntas fundamentais e o ser humano é interpelado pelo sentido da vida. O que temos feito da nossa vida e da nossa Casa Comum? O presente artigo busca refletir sobre essa questão levando em consideração os apontamentos da escatologia cristã como balizas para uma vida de esperança. O texto divide-se em dois grandes momentos. No primeiro, de modo descritivo e tendo como base as mídias noticiosas, fazemos um apanhado geral sobre as consequências da pandemia da Covid-19 sobre o mundo e, fundamentalmente, sobre o sujeito. Diante da morte, o ser humano pergunta pelo sentido da vida. No segundo momento, a escatologia, ou seja, a teologia da esperança, segundo Jürgen Moltmann, assinala caminhos possíveis para oferecer uma postura adequada às incertezas diante do definitivo e não como "respostas definitivas". Esse posicionamento tem a ver com a esperança, a principal chave de interpretação dessa teologia. Uma esperança dinâmica empenhada na transformação dos seres humanos e no cuidado com a Casa Comum.

Palavras-chave: Esperança. Teologia. Escatologia. Covid-19. Vida e morte.

Abstract: The Covid-19 pandemic has highlighted all the inequalities and social fissures. It has further revealed the existential crisis in which the postmodern individual is inserted. It is a global crisis, affecting all areas of life: from the sanitary front to the economic one. The pandemic wave is leaving behind a trail of death and suffering. In the context of social isolation, some critical issues have emerged and led the human being to question the meaning of life. What have we done with our lives and Common House? The present article seeks to reflect on this question taking into account some points

1 O artigo foi recebido em 30 de julho de 2020 e aprovado em 30 de agosto de 2020 com base nas avaliações dos pareceristas ad hoc.

2 Doutor. PUC Minas. E-mail: carlosamc04@gmail.com 
of Christian eschatology, as beacons of hope. The text is divided into two main parts. In the first, following a descriptive approach based on news media, we take a general look at the consequences of the Covid-19 pandemic for the world and, fundamentally, for the individual. In the face of death, the human being questions the meaning of life. In the second part, eschatology, that is, according to Jürgen Moltmann, the theology of hope, points out possible ways to offer appropriate answers to the uncertainties of what is definitive, but not "definitive answers". This approach has to do with hope, the main interpretative key of such a theology. A dynamic hope committed to transforming human beings and caring for the Common House.

Keywords: Hope. Theology. Eschatology. Covid-19. Life and death.

\section{Introdução}

Pandemias fazem parte da história da humanidade. Elas são mais contagiosas e letais à medida que os centros urbanos crescem, deixando um rastro de degradação no meio ambiente, desigualdade social e de acesso díspar aos recursos disponíveis nas cidades. As periferias, com suas habitações precárias, sem saneamento e congestionadas, são as que mais sofrem com o surto pandêmico. $\mathrm{O}$ vírus, a bactéria ou qualquer outro microrganismo responsável pelo surto não escolhem pessoas. Todos estão sujeitos ao contágio. Ele pode ser mais grave naquelas pessoas em estado de vulnerabilidade e que já possuem doenças crônicas. Infectologistas estão cada vez mais convictos de que o mundo globalizado de hoje vive a iminência de pandemias cada vez mais devastadoras. Elas chegam silenciosas e da epidemia para a pandemia é uma questão de dias.

Em 11 de março de 2020, o mundo recebe um alerta da Organização Mundial de Saúde (OMS) sobre uma "pandemia global"3. O comunicado é atípico, a OMS nunca havia dando um sinal desse. Rapidamente, as mídias noticiam as consequências provocadas por um novo vírus: a Covid-19. Daí em diante, testemunhamos um caos mundial, que passa por todas as instâncias da vida. A tensão se instaura. Isolamento social, comércio fechado, sistemas de saúde em colapso e muito sofrimento decorrente da morte daqueles que foram infectados e da insegurança diante da incerteza do futuro. A crise mundial já em curso é agravada ainda mais.

O momento também é propício para as perguntas fundamentais da existência. Do ponto de vista da fé cristã, a escatologia, “doutrina sobre o 'éschaton', o 'definitivo"”, está alicerçada sobre o gênero apocalíptico que floresce exatamente em momentos de crise, como o que passamos hoje, com o objetivo de dar esperança às pessoas. A teologia da esperança que emerge desse contexto pode oferecer um modo novo de ver o momento pandêmico como um tempo de graça, de esvaziamento, de escuta e de recriação. Este é o nosso objetivo: deixar ser interpelado pela "morte" (das pessoas, do sistema, dos estilos de vida etc.) para avaliar criticamente o sentido da vida.

3 WORLD HEALTH ORGANIZATION. Disponível em: <https://www.who.int/health-topics/ coronavirus\#tab=tab_1>. Acesso em: 14 jun. 2020. 
Para alcançar nosso objetivo, propomos o encontro entre o contexto da pandemia da Covid-19 e a escatologia cristã que chamamos aqui, inspirado em Jürgen Moltmann, de teologia da esperança. Na primeira parte do texto, colhemos, por meio das mídias noticiosas, informações sobre a Covid-19 e suas consequências. Sobre o novo coronavírus, ainda em pesquisa pelos especialistas, não ousamos tratar o tema como os especialistas da área o tratam. As informações oferecidas por entidades competentes da área da saúde (OMS e PAHO) juntamente com o profissionalismo do infectologista brasileiro Stephan Cunha Ujvari são suficientes para o nosso objetivo. Já o segundo momento, marcado pelo nosso lugar de fala, a teologia cristã, especificamente a escatologia, possibilita a reflexão sobre a vida, a morte e o pós-morte. À luz de viradas significativas, seja na antropologia e na hermenêutica, assumimos o labor escatológico atual que busca uma compreensão contemporânea do tema aliando novos conhecimentos à teologia por um processo de ressignificação dos termos iluminados pela esperança. Portanto não se trata de analisar os conceitos da escatologia, mas, em linhas gerais, trabalhar com categorias que provoquem a esperança de salvação para os seres humanos e a nossa Casa Comum.

O que se espera de uma teologia? Que ela seja relevante, tendo o que dizer e fazer na atualidade. Na sua tarefa pública, escutar o mundo que a cerca é fundamental. Nosso texto é pautado pela escuta atenta de um mundo que sofre as dores impostas pela pandemia da Covid-19, mas também ajustado com o seguimento de Jesus Cristo em anunciar ao mundo a boa nova de esperança do reino de Deus.

\section{Pandemias: da ficção à realidade}

"Pandemias" ocasionadas por vírus, bactérias ou outros microrganismos sempre alimentaram a imaginação de roteiristas da indústria cinematográfica. Por exemplo, O enigma de Andrômeda (1971), Epidemia (1995) e Contágio (2011) são alguns dos muitos enredos de como o mercado do cinema explora o tema da pandemia. Alguns estão longe da realidade. É o caso do Enigma de Andrômeda. Já outros, como Contágio, retratam com veracidade a cadeia de transmissão de um vírus ou um microrganismo qualquer, o desenvolvimento de uma pandemia, sua letalidade e os impactos sociais, políticos e econômicos. O público impactado pelas histórias de contágio e morte relaciona a ficção com o cenário "apocalíptico" ou "escatológico", como se os termos fossem sinônimos para anúncios futuristas marcados pelo pavor. $\mathrm{O}$ gênero moderno de ciência-ficção mistura o real com um imaginário temeroso com a extinção da raça humana.

Um vírus novo, uma pandemia, desestabiliza o mundo. Governos sentem-se apavorados diante dos impactos provocados por um surto incontrolável de doença. Os prejuízos são inevitáveis. Diante desse cenário, autoridades políticas costumam negligenciar os primeiros sinais de contaminação com receio dos danos econômicos. Quando os órgãos competentes identificam uma possível pandemia, o microrganismo já infectou muita gente. Aliás, o que caracteriza uma pandemia é exatamente o alastramento de uma doença infecciosa numa grande região geográfica. Para a Organização 
Mundial da Saúde (OMS), a pandemia envolve: 1) surgimento de uma nova doença; 2) infecção de humanos, causando uma doença séria e 3) alto índice de contágio. ${ }^{4}$

O médico infectologista brasileiro Stefan Cunha Ujvari, no livro Pandemias: a humanidade em risco, faz a transição da ficção para a realidade. Ujvari alerta para os riscos constantes de pandemias cada vez mais letais por conta da mutação de vírus, bactérias e fungos e pelo alto grau de contágio. Nos 12 capítulos do livro, o autor descreve como se dão as cadeias de contaminação que eclodem em pandemias e como essas deixam um rastro de destruição e morte. Pneumonia asiática, gripes suínas, gripe aviária, febre amarela, dengue, Zika e Chikungunya, tuberculose, superbactérias, Ebola, síndrome respiratória aguda grave (SARS) e infecções sexualmente transmissíveis (IST) como a AIDS, são alguns dos temas tratados por Ujvari.

Pandemias: a humanidade em risco foi escrito em 2011e traz algumas previsões que são confirmadas hoje, nove anos depois da sua publicação. Por exemplo, afirma o autor: "[...] há chance de pandemias por vírus semelhantes ao da SARS surgirem novamente $[. .$.$] " . "Quem disse que não estamos sujeitos a uma nova epidemia mortal$ causada por um vírus desconhecido?" "É possível imaginar uma nova pandemia pela SARS ou algum vírus semelhante. O risco existe." "A próxima pandemia poderá ser mais devastadora e a maneira como surgirá é imprevisível." ${ }^{8}$ E para finalizar, Ujvari ainda alerta:

Uma coisa é certa: vírus semelhantes ao da SARS estão por aí, nos morcegos, em qualquer lugar do planeta, aguardando a oportunidade de encontrar uma ponte para atingir o homem. Os fatos de 2003 [referência à epidemia causada pelo coronavírus SARS- $\mathrm{CoV}$ e que matou $10 \%$ das pessoas acometidas] podem se repetir, resta saber quando, onde, qual o poder de disseminação do vírus novo e sua letalidade. Novamente seremos surpreendidos pelas notícias da mídia: “A Organização Mundial da Saúde alerta o início de uma nova pandemia".

Em 2003, o mundo presenciou uma epidemia que por pouco não globalizou. O cenário inicial dessa catástrofe foi, provavelmente, o interior das matas do sudeste asiático, em que um mamífero de pequeno porte, o civeta ou gato almiscarado, protagonizou o nascimento do vírus da SARS. Da mata para os trabalhadores dos restaurantes e por toda a cidade, a pneumonia atípica, altamente contagiosa, causada por um coronavírus SARS-CoV se alastrou rapidamente pela China e por mais 30 países. O vírus se extinguiu em julho de 2003 com um saldo de oito mil infectados e mais de 900 mortes. $21 \%$ de todos os casos da SARS ocorreram com profissionais da saúde dos hospitais. A epidemia não se tornou pandemia devido, em parte, ao alerta

4 WORLD HEALTH ORGANIZATION. Disponível em: <https://www.who.int/health-topics/ coronavirus\#tab=tab_1>. Acesso em: 14 un. 2020.

5 UJVARI, Stefan Cunha. Pandemias: a humanidade em risco. São Paulo: Contexto, 2011. p. 8.

6 UJVARI, 2011, p. 10.

UJVARI, 2011, p. 21.

UJVARI, 2011, p. 23.

UJVARI, 2011, p. 23 
que a OMS disparou em março de 2003. Países entraram em estado de atenção e monitoraram pacientes suspeitos. A mídia ampliou o momento e os cuidados para evitar a contaminação. Os esforços impediram que o vírus replicasse e vidas foram salvas. ${ }^{10}$

As sociedades contemporâneas vivem sob o receio do surgimento de novas epidemias e pandemias. Criamos um mundo favorável a esses tipos de surtos. A degradação constante do meio ambiente para atender uma economia de mercado tem desencadeado alterações em todo o ecossistema. A manipulação inadequada de animais silvestres, portadores de vírus e bactérias, juntamente com a falta de higiene são práticas essenciais para a contaminação de humanos. O contágio potencializa-se na lógica urbana das grandes cidades. Viagens marítimas e, principalmente, aéreas facilitam a propagação com rapidez. Nossas cidades, marcadas por aglomerações nos transportes coletivos, nas situações de trabalho, no ambiente educacional e em eventos de entretenimento, fazem com que contaminações sejam cada vez mais frequentes. Vivemos no estresse provocado pela expectativa de uma pandemia que pode dizimar milhões de pessoas. O drama dos filmes de ficção é uma realidade cada vez mais frequente no século XXI. ${ }^{11}$

\section{A pandemia da Covid-19 e suas consequências}

31 de dezembro de 2019, a China informa ao mundo sobre um caso de pneumonia de origem desconhecida detectado na cidade de Wuhan, província de Hubei, na República Popular da China. Já no dia 03 de janeiro, são notificados os primeiros 44 casos da misteriosa pneumonia. No dia 07, as autoridades chinesas identificam um novo tipo de coronavírus e, no dia 11, a primeira morte é confirmada. No dia 23, já eram contabilizados 26 mortes e mais de 890 diagnósticos de contaminação. O mesmo cenário começa a despontar em pelo menos outros 16 países, incluindo Cingapura, Tailândia, Coreia do Sul, Japão, Taiwan e Estados Unidos. Essas informações apareceram nos jornais do mundo todo. No El PAÍS, por exemplo, o título da matéria sobre esse acontecimento é: "O vírus chinês"12. Pronto! O mundo dá sinais de que uma nova onda pandêmica avança sobre as populações.

A OMS declarou, em 30 de janeiro de 2020, que o surto da doença causada pelo novo coronavírus constitui uma "Emergência de Saúde Pública de Importância Internacional', o mais alto nível de alerta da organização. Em 11 de março de 2020, a Covid-19 foi caracterizada, pela primeira vez, pela OMS como uma "pandemia global". Especialistas criticaram a inércia do governo chinês e da OMS com relação ao alerta de emergência global para a situação. Diferente da epidemia em 2003, temos hoje uma pandemia de proporção avassaladora. O isolamento social adotado na China, deixando 11 milhões de pessoas em quarentena na cidade de Wuhan, se expandiu

${ }^{10}$ UJVARI, 2011, p. 19-21.

${ }^{11}$ UJVARI, 2011, orelha do livro.

12 NOVO Vírus Chinês. In: EL PAIS. Disponível em: <https://brasil.elpais.com/internacional/2020-01-21/ novo-virus-chines-tem-contaminacao-entre-humanos.html>. Acesso em: 16 jun. 2020. 
para todo o país e para o mundo todo. Os números assustam. De dezembro de 2019 a julho de 2020, o novo coronavírus já contaminou mais de dez milhões de pessoas, matou mais de 500 mil, em 216 países. ${ }^{13}$ Esses são os números oficiais. Na realidade, os números são bem maiores, levando em consideração os casos de subnotificação.

Ao todo, sete coronavírus humanos (HCoVs) já foram identificados: HCoV-229E, HCoV-OC43, HCoV-NL63, HCoV-HKU1, SARS-COV, causadores da síndrome respiratória aguda grave e MERS-COV, causador da síndrome respiratória do Oriente Médio. A epidemia que se alastra pelo mundo em 2020 é causada pela infecção com o coronavírus da síndrome respiratória aguda grave 2 (SARS-CoV-2). Os cientistas buscam encontrar o animal que foi a origem do surto para mapear seu código genético e ter alguma luz no descobrimento da vacina. Animais como o morcego e, na sequência, o pangolim, podem ter servido como hospedeiro do vírus antes de ser transmitido aos seres humanos. No momento, há somente hipóteses sobre a origem do vírus e novos estudos precisam ser realizados. ${ }^{14}$

A doença respiratória causada pelo coronavírus ficou conhecida mundialmente como Covid-19, do inglês Coronavirus Disease e "19" por causa do ano do seu descobrimento, 2019. Os sintomas mais comuns são:

Febre, cansaço e tosse seca. Alguns pacientes podem apresentar dores, congestão nasal, dor de cabeça, conjuntivite, dor de garganta, diarreia, perda de paladar ou olfato, erupção cutânea na pele ou descoloração dos dedos das mãos ou dos pés. Esses sintomas geralmente são leves e começam gradualmente. Algumas pessoas são infectadas, mas apresentam apenas sintomas muito leves [...] A maioria das pessoas (cerca de 80\%) se recupera da doença sem precisar de tratamento hospitalar. Uma em cada seis pessoas infectadas por Covid-19 fica gravemente doente e desenvolve dificuldade de respirar. As pessoas idosas e as que têm outras condições de saúde como pressão alta, problemas cardíacos e do pulmão, diabetes ou câncer, têm maior risco de ficarem gravemente doentes. No entanto, qualquer pessoa pode pegar a Covid-19 e ficar gravemente doente ${ }^{15}$.

As taxas de contágio e a letalidade da Covid-19 são altas. O R0 (R zero) ou número básico de reprodução mede a transmissibilidade do agente infeccioso. No caso do novo coronavírus, o R0 oscila entre 2 e 3, isto é, cada indivíduo portador transmite o vírus para duas ou três outras pessoas. Ainda não existem medicamentos antivirais aprovados para o seu tratamento e uma vacina está para ser descoberta. As recomendações essenciais para se evitar a contaminação são: higienização constante das mãos, não tocar nos olhos, nariz e boca e, principalmente, manter o isolamento social. Esta

13 WORLD HEALTH ORGANIZATION. Disponível em: <https://covid19.who.int/>. Acesso em: 01 jul. 2020.

14 PALMA, Ana. Coronavírus. Disponível em: <http://www.invivo.fiocruz.br/cgi/cgilua.exe/sys/start. htm?infoid=1438\&sid=8>. Acesso em 17 jun. 2020 .

15 ORGANIZAÇÃO PAN-AMERICANA DE SAÚDE. Disponível em: <https://www.paho.org/bra/index. php?option $=$ com_content\&view $=$ article $\& i d=6101$ : covid19\&Itemid=875>. Acesso em: 17 jun. 2020. 
última recomendação, fundamental, não é bem vista por governos, que temem o colapso financeiro dos seus países devido à paralisação das atividades comerciais. ${ }^{16}$

Isolamento social, quarentena e lockdowns são as melhores estratégias para a contenção da contaminação e preservação da vida. Para que elas sejam efetivas, são necessárias campanhas de esclarecimento como também políticas públicas mitigadoras dos efeitos econômicos e sociais do distanciamento. Nessa conjuntura, as autoridades têm uma grande responsabilidade na comunicação e nas ações visando ao bem comum. Infelizmente, muitas lideranças, irresponsavelmente, temendo o prejuízo econômico, propagam mentiras dizendo: "O vírus está sob controle"; é apenas "uma gripezinha ou resfriadinho"; aqui no nosso país "não há vírus" ou "o coronavírus é obra de Deus para punir os países que nos impuseram sanções" ${ }^{17}$. Essas falas colaboram para a elevação do potencial de contágio do vírus e para o aumento do número de casos e de óbitos pela Covid-19. São ações desumanizadoras e próprias de uma "necropolítica"18.

Não tem jeito, a pandemia existe e os números não mentem. Para evitar o contágio, a morte e o colapso do sistema de saúde, só o distanciamento social. Pessoas em casa e comércio fechado são medidas necessárias. Não há como impedir o efeito negativo de tais procedimentos sobre a economia mundial. Perde-se dinheiro, mas ganha a riqueza da vida. Os impactos da Covid-19 afetam o sistema sanitário, econômico, a sociedade, o meio ambiente e, fundamentalmente, o ser humano, que se pergunta pelo significado da existência diante do trágico cenário da morte. As pessoas empobrecidas são, mais uma vez, as mais afetadas. Como ficar em casa se elas vivem na rua em estado de vulnerabilidade? Como evitar aglomeração de pessoas se elas moram em aglomerados? Como manter a higienização se elas estão em condições insalubres? Como não se expor ao contágio se milhões não têm o privilégio de exercer o trabalho em casa? O mundo urbano de hoje é marcado por desigualdades sociais e do acesso díspar aos recursos disponíveis nas cidades. Suas periferias possuem habitações precárias, sem saneamento e congestionadas, adversas ao isolamento social e a outras medidas de combate à pandemia.

A pandemia dá o que pensar. Ela provoca a humanidade a ponderar sobre o valor da vida e da liberdade. Ela escancara a desigualdade social e a lógica perversa de um sistema econômico predatório e desumanizador. O que já era conhecido ficou mais fulgente com a pandemia. "O grito do pobre e o grito da Terra" soam mais fortes e nítidos em tempos de reclusão. "Gritam os pobres sob pesada carga de opressão

${ }^{16}$ BÓGUS, Lucia Maria Machado; MAGALHÃES, Luis Felipe Aires. Desigualdades sociespaciais e pandemia: impactos metropolitanos da Covid-19. In: PASSOS, João Décio (Org.). A pandemia do coronavírus: Onde estivemos? Para onde vamos? São Paulo: Paulinas, 2020. p. 91.

17 "GRIPEZINHA ou resfriadinho" e outras 7 frases controversas de líderes mundiais sobre o coronavírus. In: $B B C N E W S$. Disponível em: < https:/www.bbc.com/portuguese/internacional-52205918>. Acesso em: 17 jun. 2020.

18 Termo cunhado pelo cientista político camaronês Joseph-Achille Mbembe. Em oposição às categorias de "biopoder" e "biopolítica" de Michel Foucault, Mbembe propõe um ensaio para propor que as "formas contemporâneas que subjugam a vida ao poder da morte (necropolítica) reconfiguram profundamente as relações entre resistência, sacrifício e terror". MBEMBE, Achille. Necropolítica. São Paulo: N-1 Edições, 2018. p. 71. 
econômica, de discriminação social e de violência [...] Grita a Mãe Terra contra a qual está se levando uma guerra total: no solo, no subsolo, no ar, nos oceanos, em todas as frentes", afirma Leonardo Boff. ${ }^{19}$ "O ambiente humano e o ambiente natural degradam-se em conjunto", completa o papa Francisco na encíclica Laudato Si (n 48). ${ }^{20}$ É tempo de reflexão. Precisamos avaliar nossos valores. O que temos feito da nossa vida e da Casa Comum?

Há quem diga que o mundo pós-pandemia Covid-19 não será o mesmo. Será? O mundo será melhor ou pior? Só o tempo dirá. Uma coisa é certa: a humanidade já tinha consciência de uma transformação necessária. Agora, com a crise decorrente da Covid-19, a mudança é urgente e profunda "nos estilos de vida, nos modelos de produção e de consumo, nas estruturas consolidadas de poder, que hoje regem as sociedades"21. Quando as atividades apresentam nuances em relação aos fundamentos, torna-se necessário rever as estruturas que sustentam o pensar e o fazer. Crises antecedem mudanças de paradigmas. O referencial modelar de existência de ontem já não atende a demanda da vida de hoje. O momento é propício a mudanças. ${ }^{22}$

\section{Teologia da esperança}

Os meios de comunicação do mundo globalizado tornam possível a transmissão ao vivo de acontecimentos por toda parte do planeta. É desse modo que assistimos aterrorizados ao cenário de morte provocado pela pandemia da Covid-19. Hospitais lotados de gente contaminada, médicos e enfermeiros exaustos tentando salvas vidas, corpos ensacados saindo de casas e de centros de saúde, caminhões refrigerados são alocados para armazenar vítimas do coronavírus, caixões empilhados em valas comuns para suprir a demanda de enterros e o sofrimento das pessoas diante da morte de parentes e amigos. O quadro é trágico.

Perante esse contexto, fica uma constatação de cunho filosófico-teológico: a fragilidade da condição humana diante da morte interpela o sentido da vida. A morte é uma certeza. Um dia, ela chega. Ela nos põe diante de perguntas difíceis de responder e abre espaço à reflexão, não só sobre a vida, mas também sobre a soberania divina, a justiça, a ética e temas correlacionados. A caminhada do ser humano é uma busca

19 BOFF, Leonardo. Ecologia: grito da Terra, grito dos pobres. Ed. rev. amp. Petrópolis: Vozes, 2015. p. 7.

20 PAPA FRANCISCO. Laudato Si: sobre o cuidado da Casa Comum. São Paulo: Paulinas, 2015. p. 38.

${ }^{21}$ PAPA FRANCISCO, 2015, p. 6.

22 KUHN, Thomas. A estrutura das revoluções cientificas. 11. ed. São Paulo: Perspectiva, 2011. p. $218-220$. Interessante notar que, no contexto da pandemia da Covid-19, autores refletem sobre a possibilidade da aceleração de uma mudança de paradigma. Como exemplo, citamos, pelo menos, dois autores que assinalam essa ideia. Ullrich Fichtner, jornalista alemão, acredita em mundo pós-pandemia melhor e mais sustentável. Cf. <https://www.cartamaior.com.br/?/Editoria/Sociedade-e-Cultura/Uma-mudanca-deparadigma-acelerada-pelo-coronavirus/52/47342>. Acesso em: 19 jun. 2020. Já Luiz Marques, professor da Unicamp, afirma não ser mais aceitável "agendas desenvolvimentistas, típicas dos embates ideológicos do século XX". É preciso "redefinir nossa posição como sociedade e como espécie no âmbito da biosfera". Cf. $<$ https://www.unicamp.br/unicamp/noticias/2020/05/05/pandemia-incide-no-ano-mais-importante-dahistoria-da-humanidade-serao-proximas>. Acesso em: 19 jun. 2020. 
por algo que seja definitivo, profundo e abrangente. Não se contenta com o hoje sem perspectivas de um futuro mais rico e pleno. "Se não há nenhuma 'novidade radical', não sobra nada mais do que se contentar com a 'monotonia da mesmice', 'o tédio da repetição' e a 'paralisia asfixiante' do sempre igual.” O imenso labor em vista da prolongação da vida e o retardamento da morte mostram-se inúteis diante de forças que extrapolam o controle humano. ${ }^{23}$

Na caminhada da existência, à luz de sua fé, a pessoa procura entender o sentido da vida, da morte, do futuro da humanidade e do mundo. A escatologia cristã debruça-se sobre os questionamentos oriundos dessa busca de sentido. Como uma das disciplinas da teologia, a "escatologia", ou o "discurso sobre o definitivo", não oferece respostas conclusivas para a complexidade da vida, morte e pós-morte. Pelo contrário, fundamentada numa linguagem simbólica e aproximativa, a escatologia mais desperta perguntas do que respostas. Será que conseguimos conviver com o incerto, o indefinido e o impreciso? O saber teológico é inconcluso. Se não temos respostas conclusivas, temos, na escatologia, apontamentos capazes de oferecer uma postura adequada às incertezas das últimas coisas. Esse posicionamento tem a ver com a esperança, a principal chave de interpretação da escatologia.

Para o teólogo alemão Jürgen Moltmann, a teologia deve ser pensada a partir de sua meta futura, o "éschaton", o "definitivo". O termo "escatologia" como "a doutrina das últimas coisas" deve ser repensado. "A escatologia não deve ser seu fim, mas seu princípio." ${ }^{24}$ Como teorizar sobre eventos vindouros sobre os quais ninguém sabe? Por isso Moltmann pensa que "escatologia" é um termo inadequado. Não pode existir doutrina acerca das coisas finais. A doutrina é um conjunto de afirmações que surgem de experiências que se repetem e que qualquer indivíduo pode ter. "Na realidade, escatologia é idêntica à doutrina da esperança cristã, que abrange tanto aquilo que se espera, como o ato de esperar, suscitado por esse objeto.' 25

A esperança cristã surge do "Deus da esperança" e é o núcleo da teologia cristã que reflete sobre o definitivo. Ao sublinhar o elemento da "esperança" como chave hermenêutica - influência do "princípio esperança" de Ernst Bloch -, Moltmann: a) critica as escatologias que foram gestadas no século XX por serem insuficientes naquilo que almejam; b) recoloca a "escatologia", a doutrina da esperança, em um lugar de primazia no fazer teológico, tirando-a do marasmo em que se encontrava, de apêndices das teologias sistemáticas e c) insere o tema na realidade histórica, não para teorizar a seu respeito, mas para transformá-la com a práxis que surge do Deus da promessa. ${ }^{26}$

A doutrina da esperança cristã está enraizada em um gênero literário específico: o apocalíptico. Além da indistinção conceitual entre os termos "apocalipse" e "escatologia", muitas pessoas associam apocalipse com a ideia do gênero de vaticí-

\footnotetext{
${ }^{23}$ MURAD, Afonso; CUNHA, Carlos; GOMES, Paulo Roberto. Da terra ao céu: escatologia cristã em perspectiva dialogal. São Paulo: Paulinas, 2016. p. 15.

${ }^{24}$ MOLTMANN, Jürgen. Teologia da esperança: estudos sobre os fundamentos e as consequências de uma escatologia cristã. 3. ed. rev. atual. São Paulo: Teológica; Loyola, 2005. p. 31.

${ }^{25}$ MOLTMANN, 2005, p. 34.

${ }^{26}$ MOLTMANN, 2005, p. 424-453.
} 
nios ou anúncios futuristas que conhecemos pelo gênero moderno de ciências-ficção. Acreditam que o propósito dos apocalipses bíblicos é o de informar a respeito dos acontecimentos que sucederão antes do fim do mundo. Teologias e iconografias medievais contribuíram para inculcar essa ideia no imaginário religioso das pessoas. $\mathrm{Na}$ contemporaneidade, as imagens são reforçadas, por exemplo, pela indústria cinematográfica de Hollywood com filmes e seriados sobre o medo do fim do mundo. Muitas delas associadas à história de pandemias.

O apocalipse não é um gênero com o intuito de semear o medo, o terror. Seu objetivo é suscitar confiança e esperança na pessoa fiel que espera, confiantemente, o triunfo do bem sobre o mal. Enquanto gênero literário, o apocalíptico caracteriza-se pelo emprego de símbolos, de imagens e de mitos. Ele "floresceu e era popular especialmente em momentos em que o judaísmo e, em seguida, o cristianismo experimentavam graves dificuldades pelas hostilidades e pelas perseguições por parte dos poderes pagãos". Seu "propósito fundamental era infundir esperança em uma situação sentida como desesperadora, dar ânimo quando parecia melhor renunciar, afirmar a fé em momentos em que há dúvidas sobre a justiça divina". A insatisfação com o tempo presente vai, então, se expressar de maneira indireta, mediante visões, metáforas, linguagem enigmática, "revelação" (em grego, apokalypsis) de um plano ou desígnio de Deus em relação aos filhos e filhas de Deus. ${ }^{27}$

O apocalipse evoca um horizonte amplo e, sobretudo, transcendente, que, para um povo em estado de crise, como a humanidade de hoje em tempo de pandemia, funciona como alimento para a resistência e a esperança. Na teologia da esperança, Deus continua exortando as pessoas a não desanimarem diante das adversidades, a continuarem confiando nele, com a certeza de que quem perseverar se salvará e terá parte no "paraíso celestial". De que "salvação" e "paraíso celestial" estamos falando? Não como categorias de uma teologia que desvia o ser humano "deste mundo, sua morada verdadeira, o ponto de apoio de todos os seus deslocamentos e de todas as suas atividades" para um "mundo fantasmático", isto é, "um lugar de satisfação imaginária de todos os desejos e de todas as aspirações que o homem não pôde realizar aqui embaixo". Não se trata de uma fuga para um "céu", "lugar vazio e estranho à realidade", mas como um viver pleno aqui e no "além", capaz de "transformar o mundo, fazer advir nele uma modificação real" para todos e para cada um, como afirma Michel Henry na sua fenomenologia da vida. ${ }^{28}$ Então, do que se trata?

\section{Esperança para os seres humanos}

Salvação não é um conceito abstrato de um ato mágico que acontece no fim de nossa vida. Ela é um processo dinâmico que marca toda a existência humana. Sua

27 ARENS, Eduardo. A Bíblia sem mitos: uma introdução crítica. 3. ed. rev. aum. São Paulo: Paulus, 2007. p. 110-111.

28 HENRY, Michel. Eu sou a verdade: por uma filosofia do cristianismo. São Paulo: E Realizações, 2015. p. 329-332. 
origem etimológica, do grego "soteria", remete a um campo semântico amplo: libertação, cura e salvação eterna, total e definitiva. ${ }^{29}$ É no decorrer desta existência que Deus, junto com a pessoa e com seu consentimento, realiza a salvação. Sua meta final é vida em plenitude. Deus, que almeja a salvação de todos, ressuscita o ser humano na morte, assim como ele ressuscitou seu Filho Jesus. Isso significa que o próprio Deus abre para todas as pessoas novas dimensões da vida, dimensões que chamamos salvação, plenificação e intensificação máxima da existência.

No contraste dos planos surge a consciência do limiar entre a vida e a morte. O binômio vida/morte apresenta balizas inquestionáveis, concretas. Elas pedem posicionamentos. Diante do impacto da morte fica o que é ou não é real. O ser, primário, fica evidente e o ter assume um papel secundário. A morte interpela sobre o sentido da vida. $\mathrm{O}$ morrer está estreitamente relacionado com todos os planos da existência humana. Na teologia da esperança, a morte não é o fim da existência humana, mas o momento da sua redimensionalização e plenificação. É uma morte-ressurreição, isto é, depois da morte o ser humano entra num modo de ser que extrapola a esfera espaçotemporal e passa à realidade eterna de Deus. Assim não se pode dizer que esperamos a ressurreição no "final dos tempos", porque na eternidade não existe esse final cronológico. Por isso a "espera" pela ressurreição final é uma representação equivocada ao modo de existir da eternidade. Não há, no mundo dos mortos, medida de tempo. Eles já se encontram no mundo da ressurreição. A ressurreição não se dá em "três dias" nem no "último dia", mas "hoje". "Hoje estarás comigo no paraíso", diz Jesus àquele que foi crucificado ao seu lado e que também está morrendo (Lc 23.23). ${ }^{30}$

A fé na ressurreição é fundamental para a pessoa cristã e uma inspiração para o mundo. "E, se não há ressurreição de mortos, então, Cristo não ressuscitou. E, se Cristo não ressuscitou, é vã a nossa pregação, e vã, a vossa fé", afirma o apóstolo Paulo (1Co 15.13-14). Ressuscitando Jesus, Deus revela seu projeto salvífico universal e começa a realizar a "nova criação" libertada para sempre do mal. A esperança cristã de que a ressurreição acontece imediatamente na morte funda-se na própria ressurreição de Jesus. Assim como o Pai o ressuscitou, nós também seremos ressuscitados. Deus manifesta-se na morte de cada ser humano de forma nova e criativa. Ele ressuscita homens e mulheres para novas dimensões de vida que vão além de tudo o que se pode imaginar e torna-se realidade a vontade divina revelada na vida de Jesus Cristo: vida em abundância (Jo 10.10).

Medard Kehl, inspirado em Hegel, utiliza-se do tríplice conceito do termo "suprassumir" (aufheben) para explicar o significado da expressão "ressurreição dos mortos". Para Hegel, diz ele, "suprassumir" significa: (1) conservar; (2) revogar e (3) erguer. Tal conceito tríplice aplicado à ressurreição significa:

(1) O amor de Deus conserva tudo o que é importante na vida pessoal e na história humana para a comunhão com Deus e definitivamente reconciliada no Reino de Deus [...]

\footnotetext{
29 RUSCONI, Carlo. Dicionário do grego do Novo Testamento. São Paulo: Paulus, 2003. p. 448.

${ }^{30}$ CUNHA, Carlos. A ressurreição. In: MURAD; CUNHA; GOMES, 2016, p. 73.
} 
(2) O amor de Deus revoga tudo o que não pode ser incorporado nessa reconciliação definitiva [...] (3) Todo o "fruto" de nossa vida, digno de conservação, que levamos à consumação é aceito, acolhido pelo amor de Deus e conduzido, por ele, à completa "maturação" (é "erguido")

Se na morte de Jesus Deus mostra-se fiel à natureza, na ressurreição, concretiza o amor gratuito por cada ser humano e por todas as criaturas. Deus não abandona sua criação no colapso da morte, mas a ressuscita para a vida plena. Por meio da ressurreição, revela-se solidário com toda a criação e descortina a sua meta final: vida plena de comunhão com ele. O que aconteceu com Jesus explicita-nos o núcleo do projeto salvífico universal. A Páscoa, passagem da morte para a "vida eterna", antecipa no dinamismo histórico o que sucederá com todo ser criado. "Vida eterna", equivocadamente entendida como continuação infinita da vida atual, é um salto qualitativo da existência. "Significa [...] a participação em uma vida de outra qualidade, e, para quem crê em Jesus (e age em conformidade com esse crer), essa participação começa já [...] É a vida do âmbito de Deus, vivida na fé, desde já. É o definitivo de Deus em nossa vida."32

Ser ressuscitado por Deus significa ter os bons frutos da vida conservados; é ter todas as dores e feridas revogadas e, por fim, é ser erguido por ele para a vida nova no desfrute da sua presença. Na ressurreição de Jesus explicita-se o modelo da nossa e torna-se fonte de esperança. Jesus ressuscitado e exaltado por Deus faz emergir, nas pessoas que creem, a esperança, sempre constante de vida plena, apesar das adversidades do tempo presente. A ressurreição revela-nos o rosto amoroso de Deus e seu projeto salvífico universal. Além disso, mostra-nos, com profundidade, o mistério do ser humano e possibilita-nos conhecer o caminho da plena realização humana. Esse caminho se faz pelo seguimento, ao modo de ser de Jesus Cristo.

A esperança que a salvação suscita possui dimensões pessoal e coletiva. Se, por um lado, cremos na ressurreição pessoal, "na minha ressurreição", por outro, ao mesmo tempo cremos na ressurreição de todos, "na nossa ressurreição". Nesse sentido, o acontecimento pós-morte de Jesus Cristo revela-nos, de modo pleno, o projeto salvífico universal e o que cada um de nós passará na morte. Ninguém está excluído desse dinamismo.

\section{Esperança para a Casa Comum}

Deus não fica fora da história. Ele participa ativamente dos acontecimentos do mundo. As catástrofes do presente podem parecer uma negação de toda a esperança, mas tal aparência é um engano. O conceito de "revelação" testifica essa participação divina na história. Deus não se deu a conhecer nos relatos, mas nos acontecimentos concretos da vida. Revelação é a manifestação da presença do Extraordinário no or-

31 KEHL, Medard. O que vem depois do fim? Sobre o acaso do mundo, consumação, renascimento e ressurreição. São Paulo: Loyola, 2001. p. 133-136.

32 KONINGS, Johan. Evangelho segundo João: amor e fidelidade. São Paulo: Loyola, 2005. p. 225. 
dinário da existência, mediante a qual ele se dá a conhecer e concede ao mundo a possibilidade de reconhecê-lo. Revelação é uma realidade relacional, dialogal. Quanto maior a interação entre os humanos e toda criação maior o conhecimento sobre, a partir e com o Divino. "Conhecimento", aqui, não significa aquisição de informações sobre determinado objeto, mas como caminho para a comunhão. "Pelo conhecimento, participamos da vida do outro [...] transforma o conhecedor em elemento participativo do conhecido [...] O conhecimento tem o mesmo alcance que o amor, a simpatia e a participação." ${ }^{33}$

A história não é predeterminada, ela possui um dinamismo dialético. Progresso e retrocesso, aceleração e estagnação, morte e vida compõem o cenário da narrativa da existência. É dentro desse quadro histórico dinâmico que a teologia da esperança emerge interpelando a contemporaneidade com perguntas que integram o ser humano e o mundo. Como a teologia pode contribuir para que o ser humano tenha consciência da sua responsabilidade com a Casa Comum? Como a salvação abarca também o meio ambiente?

A salvação inclui o universo em toda a sua totalidade. A teologia paulina reforça essa ideia ao afirmar que, em Jesus Cristo, "foram criadas todas as coisas [...]. Tudo foi criado por ele e para ele" ( $\mathrm{Cl} 1.16)$. A fórmula ternária, "nele, por ele e para ele", de origem panenteísta, isto é, Deus está em tudo e não "Deus é tudo" (panteísmo), é compreendida numa perspectiva histórico-salvífica. Leonardo Boff esclarece:

Tudo não é Deus. Mas Deus está em tudo e tudo está em Deus, por causa da criação, pela qual Deus deixa sua marca registrada e garante sua presença permanente na criatura (Providência). A criatura sempre depende de Deus e o carrega dentro de si. Deus e mundo são diferentes. Um não é o outro. Mas não estão separados ou fechados. Estão abertos um ao outro. Encontram-se sempre mutuamente implicados. Se são diferentes é para poderem se comunicar e estarem unidos pela comunhão e mútua presença ${ }^{34}$.

A realidade de toda a criação, o humano e o mundo, recebe em Cristo um lugar e sentido definitivos. Deus-Pai, por meio do seu Filho e no poder do Espírito atua em tudo e em todos. Não se deve desprender a vida humana do contexto do meio ambiente. Há unidade entre a humanidade e a Terra. Essa ideia surge como chave hermenêutica para a teologia da criação que vê no relato das origens uma relação de cuidado e salvação: "Tomou, pois, o Senhor Deus ao homem e o colocou no jardim do Éden para cultivar e o guardar" (Gn 2.15). O mundo criado está destinado, não à destruição, mas à plenitude a ser alcançada em Cristo. O planeta tem uma marca de filiação e, portanto, de redenção. "A crença na criação está a serviço da crença na salvação, porque para esta a salvação surge de novas criações de Deus. Por isso a criação no início pode ser louvada como ato salvífico, e a redenção pode ser esperada como nova criação."35

33 MOLTMANN, Jürgen. Trindade e Reino de Deus: uma contribuição para a teologia. Petrópolis: Vozes, 2000. p. 24.

34 BOFF, 2015, p. 249.

35 MOLTMANN, Jürgen. Ciência e sabedoria: um diálogo entre ciência natural e teologia. São Paulo: Loyola, 2007. p. 60. 
Diante da "morte das utopias" que assombrava a modernidade e assombra ainda o tempo presente, o discurso escatológico, e sua esperança, se torna realidade possível no reino de Deus anunciado na concretude dos feitos de Jesus. Esse Reino tem um rosto, uma identidade, é o reino de "Deus" e, como tal, expressa dinamicidade, abertura e orientação. Enquanto conceito aberto e para além da tradição judaico-cristã, o reino de Deus significa, em termos abstratos, uma sociedade de justiça, igualdade e abundância. Já na perspectiva concreta, esse Reino orienta ações históricas diversas impulsionando movimentos de salvação, libertação. O reino de Deus é universal, abarcando toda a criação, principalmente os excluídos e, aí, se encaixam não só as pessoas empobrecidas como a própria natureza. Toda a humanidade e todo o mundo estão envolvidos "em uma história coletiva com a qual Deus faz uma história de salvação"36.

A consciência do reino de Deus dá força para fazer dele uma realidade concreta no presente e esperança de um futuro melhor. A esperança é ativa e a força propulsora para o agir transformador deste mundo. É na dinâmica entre o "já", no presente, e o "ainda não", do futuro, que o Reino transforma a realidade. A esperança no reino de Deus está pautada no "esperar" - termo que evoca atitude, ação -, diferente do "aguardar", modo passivo. Essa transformação proposta pelo Reino se dá de forma individual e coletiva, quer dizer, é força crítica diante dos sistemas sociais e políticos absolutistas. A consciência do Reino torna-se plena quando desemboca em ações transformadoras, libertadoras. Pensar o mundo é importante, mas o fundamental é transformá-lo.

As verdades escatológicas, com sentido para os nossos dias, são compreendidas como processos dialéticos e não como acontecimentos isolados. "Fim do mundo", por exemplo, não é catástrofe cósmica, mas o desaparecimento progressivo e dialético de um sistema-mundo marcado por injustiças e violência. "Fim do mundo" é processo dinâmico, pelo qual Deus conduz sua criação ao estado de plenificação (Jo 3.19; 12.31). Tal procedimento implica uma transformação do planeta inteiro. Já está em andamento dentro da história o processo pelo qual o novo mundo de Deus transforma o velho mundo do "anti-Reino". Ressuscitado Jesus Cristo, Deus confirma que o seu Reino "já começou, porque Ele se torna presente, de maneira qualitativamente nova e definitiva como: Deus fiel, Deus da vida e mais forte do que a morte"37.

Esse novo que irrompe no mundo é possível pela graça de Deus. Sua presença plena, "parousia" no grego, implica a plenificação do ser humano e do planeta. Ela já começou como processo de cristificação das relações entre as criaturas. Há uma profunda relação entre a ressurreição de Jesus, nossa própria ressurreição e a transformação da Casa Comum num "novo céu e numa nova terra". A parousia é "mais que uma vinda de Cristo ao mundo, é a ida do mundo e dos homens à forma da existência gloriosa de Cristo ressuscitado. Ela é descrita como o último estágio de nossa transformação em Cristo"38.

${ }^{36}$ GEFFRÉ, Claude. La teología de las religiones no-cristianas: veinte años después del Vaticano II. In: Encuentro islamo-cristiano, Madri, n. 217, mayo 1990. p. 13.

37 BLANK, Renold. Escatologia do mundo: o projeto cósmico de Deus. São Paulo: Paulus, 2001. p. 321-333.

38 PEÑA, Juan L. Ruiz de la. La pascua de la creación. Madri: Biblioteca de autores cristianos, 1996. p. 139. 


\section{Considerações finais}

Para algumas pessoas, o ano de 2020 é um ano perdido. O isolamento social, como melhor iniciativa para combater a pandemia da Covid-19, provocou um colapso no sistema financeiro de todo o mundo. As certezas conquistadas por um sistema econômico que se dizia infalível, absoluto e responsável pelo progresso, ruíram diante da ação de um vírus. Encontramo-nos sem direção. Repentinamente, a vida toma um novo rumo e não sabemos lidar com as consequências, amplas e complexas, da pandemia. A impressão que se tem é que o momento provoca o ser humano a refletir sobre o significado da vida e tudo o que ela representa. É o caos, a desordem, o conflito e a morte que nos desinstalam dos lugares acomodados rumo à novidade. Portanto este ano pode ser um tempo de aprendizagem e crescimento existencial.

Esperança é uma palavra forte para o nosso tempo. Não como significado abstrato, mas como sentido para a transformação. $\mathrm{O}$ afastamento social imposto tem feito muita gente redescobrir valores esquecidos. Redescobre-se a importância de manter o corpo saudável, do valor da união familiar, de uma habilidade deixada para trás, do lugar da espiritualidade e outras graças que a vida nos proporciona e que, por algum motivo, deixamos de valorizar. O tempo pandêmico revela como nos afastamos de nós mesmos, do próximo, do meio ambiente e de Deus. A pandemia revelou o vazio existencial e um estilo de vida sem lugar para o outro.

De tantas lições que podemos tirar desse momento, há uma que se manifesta como ironia e importante reflexão. A globalização encurtou os espaços e conectou o mundo todo. A velocidade do mundo tecnocientífico priorizou os espaços de modo que o sujeito de hoje "corre como louco para resolver tudo no momento presente, para tentar tomar posse de todos os espaços de poder e autoafirmação"39. O isolamento social barra essa lógica ativista e presentista e faz pensar sobre o que o papa Francisco afirmou na exortação apostólica Evangelli Gaudium: "O tempo é superior ao espaço" $\left(\mathrm{n}^{\circ}\right.$ 222). "O tempo ordena, ilumina e transforma os espaços."

É tempo de crise e de incerteza, mas também e, sobretudo, é tempo de esvaziamento, de esperança e de graça. Os apontamentos da teologia da esperança podem contribuir para uma redescoberta de sentido existencial. A vida não se esgota na disposição do momento, mas tem uma inspiração maior e mais alta. É momento de uma espiritualidade engajada capaz de nos libertar de uma mentalidade eficiente do tempo e nos lançar em uma "mística dos olhos abertos e das mãos operosas", consciente da situação dos seres humanos e da Casa Comum. Uma teologia da esperança que tem o que dizer "precisa ser um discurso sensível ao tempo, que não só explica e ensina, mas também experimenta e aprende", conclui Johann Baptist Metz. ${ }^{41}$

39 PAPA FRANCISCO. Evangelii Gaudium: sobre o anúncio do evangelho no mundo atual. São Paulo: Paulinas, 2013. p. 179.

40 PAPA FRANCISCO, 2013, p. 179.

${ }^{41}$ METZ, Johann Baptist. Mística de olhos abertos. São Paulo: Paulus, 2013. p. 15. 


\section{Referências}

ARENS, Eduardo. A Bíblia sem mitos: uma introdução crítica. 3. ed. rev. aum. São Paulo: Paulus, 2007.

BÍBLIA de Estudo Almeida. São Paulo: Sociedade Bíblica do Brasil, 1999.

BLANK, Renold. Escatologia do mundo: o projeto cósmico de Deus. São Paulo: Paulus, 2001. BOFF, Leonardo. Ecologia: grito da Terra, grito dos pobres. Ed. rev. amp. Petrópolis: Vozes, 2015. BÓGUS, Lucia Maria Machado; MAGALHÃES, Luis Felipe Aires. Desigualdades socioespaciais e pandemia: impactos metropolitanos da Covid-19. In: PASSOS, João Décio (Org.). A pandemia do coronavírus: Onde estivemos? Para onde vamos? São Paulo: Paulinas, 2020.

GEFFRÉ, Claude. La teología de las religiones no-cristianas: veinte años después del Vaticano II. Encuentro islamo-cristiano, Madri, n. 217, mayo 1990.

"GRIPEZINHA ou resfriadinho" e outras 7 frases controversas de líderes mundiais sobre o coronavírus. BBC NEWS. Disponível em: <https://www.bbc.com/portuguese/internacional-52205918>. Acesso em: 17 jun. 2020.

HENRY, Michel. Eu sou a verdade: por uma filosofia do cristianismo. São Paulo: E Realizações, 2015. KEHL, Medard. O que vem depois do fim? Sobre o acaso do mundo, consumação, renascimento e ressurreição. São Paulo: Loyola, 2001.

KONINGS, Johan. Evangelho segundo João: amor e fidelidade. São Paulo: Loyola, 2005.

KUHN, Thomas. A estrutura das revoluções científicas. 11. ed. São Paulo: Perspectiva, 2011. MBEMBE, Achille. Necropolítica. São Paulo: N-1 Edições, 2018.

METZ, Johann Baptist. Mística de olhos abertos. São Paulo: Paulus, 2013.

MOLTMANN, Jürgen. Trindade e Reino de Deus: uma contribuição para a teologia. Petrópolis: Vozes, 2000.

Teologia da esperança: estudos sobre os fundamentos e as consequências de uma escatologia cristã. 3. ed. rev. atual. São Paulo: Teológica; Loyola, 2005.

. Ciência e sabedoria: um diálogo entre ciência natural e teologia. São Paulo: Loyola, 2007.

MURAD, Afonso; CUNHA, Carlos; GOMES, Paulo Roberto. Da terra ao céu: escatologia cristã em perspectiva dialogal. São Paulo: Paulinas, 2016.

NOVO Vírus Chinês. EL PAIS. Disponível em: <https://brasil.elpais.com/internacional/2020-01-21/ novo-virus-chines-tem-contaminacao-entre-humanos.html>. Acesso em: 16 jun. 2020.

ORGANIZAÇÃO PAN-AMERICANA DE SAÚDE. Disponível em: <https://www.paho.org/ bra/index.php?option $=$ com_content $\&$ view $=$ article $\& i d=6101:$ covid $19 \&$ Itemid $=875>$. Acesso em: 17 jun. 2020.

PALMA, Ana. Coronavírus. Disponível em: <http://www.invivo.fiocruz.br/cgi/cgilua.exe/sys/ start.htm?infoid=1438\&sid=8>. Acesso em: 17 jun. 2020.

PAPA FRANCISCO. Evangelii Gaudium: sobre o anúncio do evangelho no mundo atual. São Paulo: Paulinas, 2013.

Laudato Si: sobre o cuidado da Casa Comum. São Paulo: Paulinas, 2015.

PEÑA, Juan L. Ruiz de la. La pascua de la creación. Madri: Biblioteca de autores cristianos. 1996. RUSCONI, Carlo. Dicionário do grego do Novo Testamento. São Paulo: Paulus, 2003.

UJVARI, Stefan Cunha. Pandemias: a humanidade em risco. São Paulo: Contexto, 2011.

WORLD HEALTH ORGANIZATION. Disponível em: < https://covid19.who.int/>. Acesso em: 01 jul. 2020. 